South Dakota State University

Open PRAIRIE: Open Public Research Access Institutional

Repository and Information Exchange

Agronomy, Horticulture and Plant Science

Department of Agronomy, Horticulture, and

Faculty Publications

Plant Science

$12-2020$

Tillage Method and Glyphosate-Resistant Alfalfa Termination

Timing Affect Soil Properties and Subsequent Corn Yield

Jason Clark

Matt A. Yost

Grant E. Cardon

Corey V. Ransom

J. Earl Creech

Follow this and additional works at: https://openprairie.sdstate.edu/plant_faculty_pubs

Part of the Agronomy and Crop Sciences Commons 
Crop Economics, Production, \& Management

\title{
Tillage method and glyphosate-resistant alfalfa termination timing affect soil properties and subsequent corn yield
}

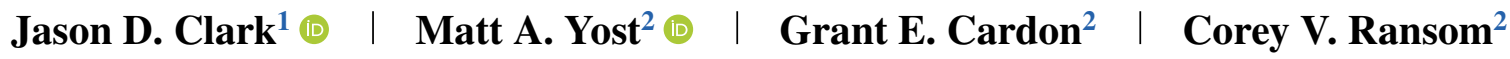 \\ J. Earl Creech ${ }^{2}$ ๑
}

${ }^{1}$ South Dakota State Univ., 1148 Medary Ave., Brookings, SD 57007, USA

${ }^{2}$ Utah State Univ., 4820 Old Main Hill, Logan, UT 84322, USA

\section{Correspondence}

J. Earl Creech, Utah State Univ., 4820 Old Main Hill, Logan, UT 84322, USA.

Email:earl.creech@usu.edu

Funding information

Utah Agricultural Experiment Station,

Grant/Award Number: 9336

\begin{abstract}
Application of glyphosate [N-(phosphonomethyl) glycine]-containing herbicides and tillage, alone or in combination, has been the standard for removing declining alfalfa (Medicago sativa L.) stands. With glyphosate no longer an option to control glyphosate-resistant alfalfa, different termination strategies are needed. Field studies across four site-years in Utah evaluated the effect of tillage type and timing (fall conventional till, spring conventional till, fall strip-till, spring strip-till, and no-till) and herbicide timing (fall, spring, in-crop, and no herbicide) of 2,4-D (2,4dichlorophenoxyacetic acid) and dicamba (3,6-dichloro-2-methoxybenzoic acid) on penetration resistance, alfalfa regrowth, corn (Zea mays L.) emergence rate, and silage corn yield. Across tillage treatments, fall, spring, and in-crop herbicide timings compared with no herbicide reduced alfalfa stem count and biomass by at least 74 and 92\%, respectively. Emergence rate was greatest under fall and spring conventional till or spring strip-till compared with fall strip-till or no-till. Silage corn yield was greatest and similar with fall or spring herbicide applications for all tillage systems and conventional tillage with an in-crop herbicide application (19-27 Mg $\mathrm{ha}^{-1}$ ), followed by in-crop herbicide application for conservation tillage systems and fall and spring conventional till without herbicide application (14-20 $\left.\mathrm{Mg} \mathrm{ha}^{-1}\right)$, and lastly when only conservation tillage was used to terminate alfalfa $\left(5-15 \mathrm{Mg} \mathrm{ha}^{-1}\right)$. Silage corn yield can be optimized when glyphosate-resistant alfalfa is terminated with herbicides prior to planting, regardless of tillage type or timing. Termination of glyphosate-resistant alfalfa by herbicides after corn emergence, depending on tillage, reduces silage corn yield 9-19\%.
\end{abstract}

\section{1 | INTRODUCTION}

Crop rotation from alfalfa (Medicago sativa L.) to corn (Zea mays L.) is common in dairy production areas of the United States. When rotating from alfalfa to corn, herbicides, tillage, or a combination of both can be used to terminate the declining alfalfa stand and prepare the seedbed for corn planting.
The application of glyphosate-containing herbicides to terminate alfalfa has been the standard choice among growers because of its effectiveness in controlling alfalfa (Buhler \& Mercurio, 1988; Bullied, Entz, \& Smith , 1999; Malhi et al., 2007). However, glyphosate-resistant alfalfa has been commercialized and is now widely planted throughout the United States. With this new technology, glyphosate is no longer an 
alfalfa control option (Rogan \& Fitzpatrick, 2004; Steckel, Hayes, Montgomery, \& Mueller, 2007).

A mixture of the herbicides 2,4-D (2,4dichlorophenoxyacetic acid) and dicamba (3,6-dichloro2-methoxybenzoic acid) has been suggested as an alternative to glyphosate for alfalfa stand removal (Buhler \& Mercurio, 1988; Moomaw \& Martin, 1976; Van Deynze et al., 2004). The labels for these products suggest that this herbicide combination will require different application timings than glyphosate due to restrictions on application timing and subsequent alfalfa harvest, feeding, tillage, and subsequent corn planting. For example, a preharvest application of glyphosate can be made $36 \mathrm{~h}$ before alfalfa harvest or grazing to terminate the alfalfa stand, and then tillage and corn planting can take place immediately (Monsanto, 2019). No such application can be made with 2,4-D or dicamba alone or in combination. With these, the application must be delayed until alfalfa has reached $10-15 \mathrm{~cm}$ of post-harvest regrowth, then tillage and planting must be delayed another 7-14 d to allow for sufficient herbicide translocation for alfalfa control and to minimize the risk of corn injury (BASF, 2010; Winfield, 2020).

Timing of herbicide application is critical to balancing the need for effective alfalfa stand removal while protecting corn yield, particularly as it relates to growth regulator herbicides (i.e., 2,4-D and dicamba) and glyphosate-resistant alfalfa. Findings from previous research on terminating alfalfa stands with fall or early spring herbicide applications have been inconsistent (Bullied et al., 1999; Malhi et al., 2007; Moomaw \& Martin, 1976). Aside from traditional fall or spring alfalfa stand termination timings, some growers prefer a double crop system where the first cutting of alfalfa is harvested and then corn is immediately planted. In such a system with glyphosate-resistant alfalfa, waiting for sufficient alfalfa regrowth to apply growth regulator herbicides plus another 7 $14 \mathrm{~d}$ to till and plant would decrease the length of the growing season available to corn, thereby reducing yield (Darby \& Lauer, 2002; Van Roekel \& Coulter, 2011). An alternative would be to plant corn immediately after glyphosate-resistant alfalfa harvest and then apply growth regulator herbicides to terminate the glyphosate-resistant alfalfa stand after corn emergence. Although this option would lengthen the growing season available for corn, it is unknown how the in-crop herbicide application would influence alfalfa control and corn yield compared with a traditional fall or preplant spring application.

Conventional tillage techniques such as moldboard plowing, subsoiling, and disking are commonly used to terminate alfalfa, alleviate compaction, and provide a seedbed for planting corn. However, these practices also decrease soil moisture, increase erosion (Mohr, Entz, Janzen, \& Bullied, 1999), decrease organic matter, decrease overall soil productivity (Entz, Bullied, \& Katepa-Mupondwa, 1995), decrease soil structure, and increase potential for soil crusting

\section{Core Ideas}

- Herbicides alone or combined with tillage adequately controlled glyphosate-resistant alfalfa.

- Corn emerged faster with conventional-till or spring strip-till than with fall strip-till or no-till.

- Corn yield was similar regardless of tillage when herbicides were applied before corn planting.

- Terminating alfalfa with herbicides after corn emergence reduced silage corn yield.

(Bullied et al., 1999). To mitigate these negative effects, growers have been moving to conservation tillage practices such as no-till and strip-till. These systems leave more plant residue on the soil surface, preserve soil structure, decrease the potential for erosion (Moyer, Clapperton, \& Boswall, 2003), improve soil moisture, decrease nitrate $\left(\mathrm{NO}_{3}{ }^{-}\right)$leaching, and decrease nitrous oxide greenhouse emissions (Malhi, Lemke, \& Schoenau, 2009). However, compared with conventional tillage systems, no-till systems can have greater compaction (Vyn \& Raimbult, 1993), reduced corn emergence rates (Al-Darby \& Lowery, 1987; Licht \& Al-Kaisi, 2005), and lower corn yield (Aflakpui, Vyn, Hall, Anderson, \& Swanton, 1993). An alternative to conventional-till and no-till systems is strip-till, where tillage occurs only in a narrow band that encompasses the planting area, while the between row area is left undisturbed to reduce erosion and preserve soil structure. (Vetsch \& Randall, 2002). The corn emergence rates and yields of this system have been higher than no-till and similar to that of conventional-till (Beyaert, Schott, \& White, 2002; Licht \& Al-Kaisi, 2005; Randall, Vetsch, \& Murrell, 2001; Vetsch \& Randall, 2004). However, when tillage is reduced or eliminated, herbicide application is required to adequately control the alfalfa and protect corn yield (Randall et al., 2001; Vetsch \& Randall, 2004). How tillage interacts with herbicides for glyphosate-resistant alfalfa stand removal and subsequent corn production has not been addressed in the literature.

Application of a glyphosate-containing herbicide and tillage, alone or in combination, has been the standard since glyphosate was developed for removing declining alfalfa stands in preparation for planting corn. The advent and widespread adoption of glyphosate-resistant alfalfa, coupled with farmer interest to reduce or eliminate tillage, has created a need for new management practices for glyphosateresistant alfalfa stand termination. Therefore, the objectives of this research were (a) to measure the effect of tillage type and timing on soil compaction and (b) to determine the effect of herbicide timing, tillage type and timing, and their interaction 
on glyphosate-resistant alfalfa termination, corn emergence rate, and silage corn yield for first-year corn after alfalfa.

\section{2 | MATERIALS AND METHODS}

\subsection{Experimental design}

This study was conducted on a coarse-textured soil in Cornish and a fine-textured soil in Cache Junction, Utah, in 2012 and 2013, with four site-years over the 2-yr period (Table 1). Soil series, texture, and taxonomic class data were obtained from USDA-NRCS (Soil Survey Staff, 2014a, 2014b). The Cornish and Cache Junction sites were located approximately $19 \mathrm{~km}$ apart. A weather station that was within $11 \mathrm{~km}$ of both sites was used to collect weather data for the $2 \mathrm{yr}$ of this study (2012-2013), which were compared with the long-term average of the area (1944-2013) (Table 2). The alfalfa fields were glyphosate resistant and had been in commercial production for 5-7 yr at the time of stand termination. Each experiment started in the fall of the last year the alfalfa stand was in production.

The experimental design was a randomized complete block in a split-plot arrangement with four replications. The whole plot treatments consisted of five individual combinations of tillage type and timing (fall conventional tillage, spring conventional tillage, fall strip-till, spring strip-till, and no-till). The subplot treatments consisted of four herbicide application timing treatments (fall, spring, in-crop [after corn emergence], and nontreated control [no herbicide application]). Whole plots measured $3.0 \mathrm{~m}$ wide (four rows) and $122.0 \mathrm{~m}$ long in 2012 and $146.3 \mathrm{~m}$ long in 2013.

Tillage type and timing treatments were completed a minimum of 7-14 d after herbicide treatment according to herbicide label guidelines. The fall and spring conventional tillage treatments consisted of subsoiling to a depth of $45 \mathrm{~cm}$ on 45-cm centers with a seven-shank subsoiler (Model S207 Ripper, Miskin) and then disked to a depth of $15 \mathrm{~cm}$ using a heavy disk (Model 5815W, Kuhn Krause, Inc.). Final seedbed preparation was completed with a roller harrow (Brillion Farm Equipment, Landoll Corporation) before planting. Fall and spring strip-till treatments were tilled to a depth of $20 \mathrm{~cm}$ and a width of $25 \mathrm{~cm}$ using a two-row strip-till implement (Model 839-076, 1tRIPr, Orthman). Corn seed was planted directly into the strip-tilled area without further seedbed preparation. The no-till treatment received no tillage before planting.

Subplots measured $3.0 \mathrm{~m}$ wide and $30.5 \mathrm{~m}$ long in 2012 and $36.6 \mathrm{~m}$ long in 2013. The herbicide timing treatments were completed by applying a tank mixture of 2,4-D LV6 (2-ethylhexyl ester of 2,4-dichlorophenoxyacetic acid) at $784 \mathrm{~g}$ a.e. $\mathrm{ha}^{-1}$ and dicamba (3,6-dichloro-2-methoxybenzoic acid) at $280 \mathrm{~g}$ a.e. $\mathrm{ha}^{-1}$, plus nonionic surfactant at $0.25 \%$ $\mathrm{v} / \mathrm{v}$ at a spray volume of $140 \mathrm{~L} \mathrm{ha}^{-1}$. The range in alfalfa

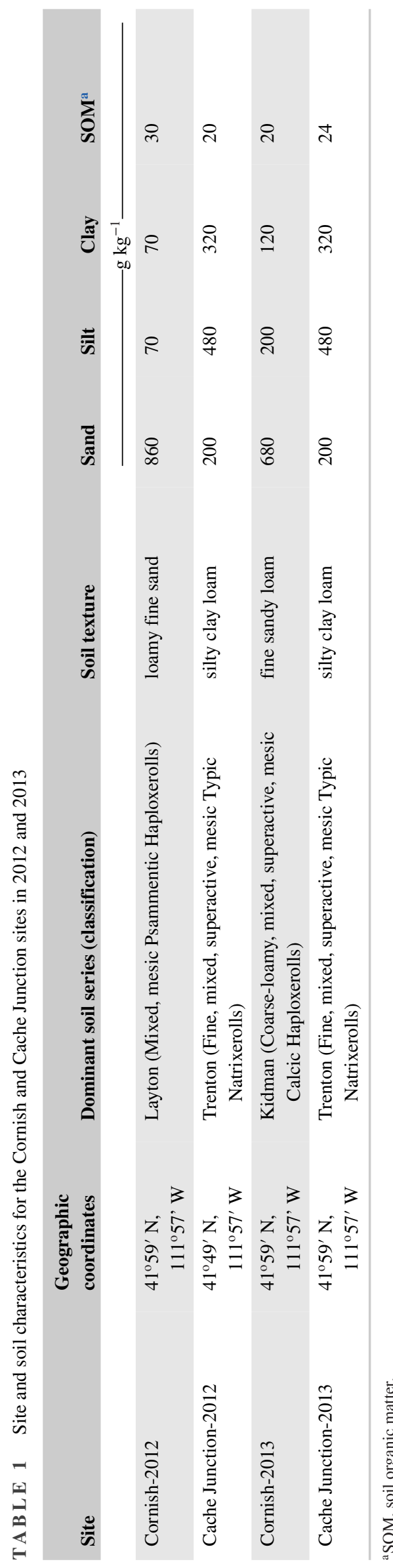




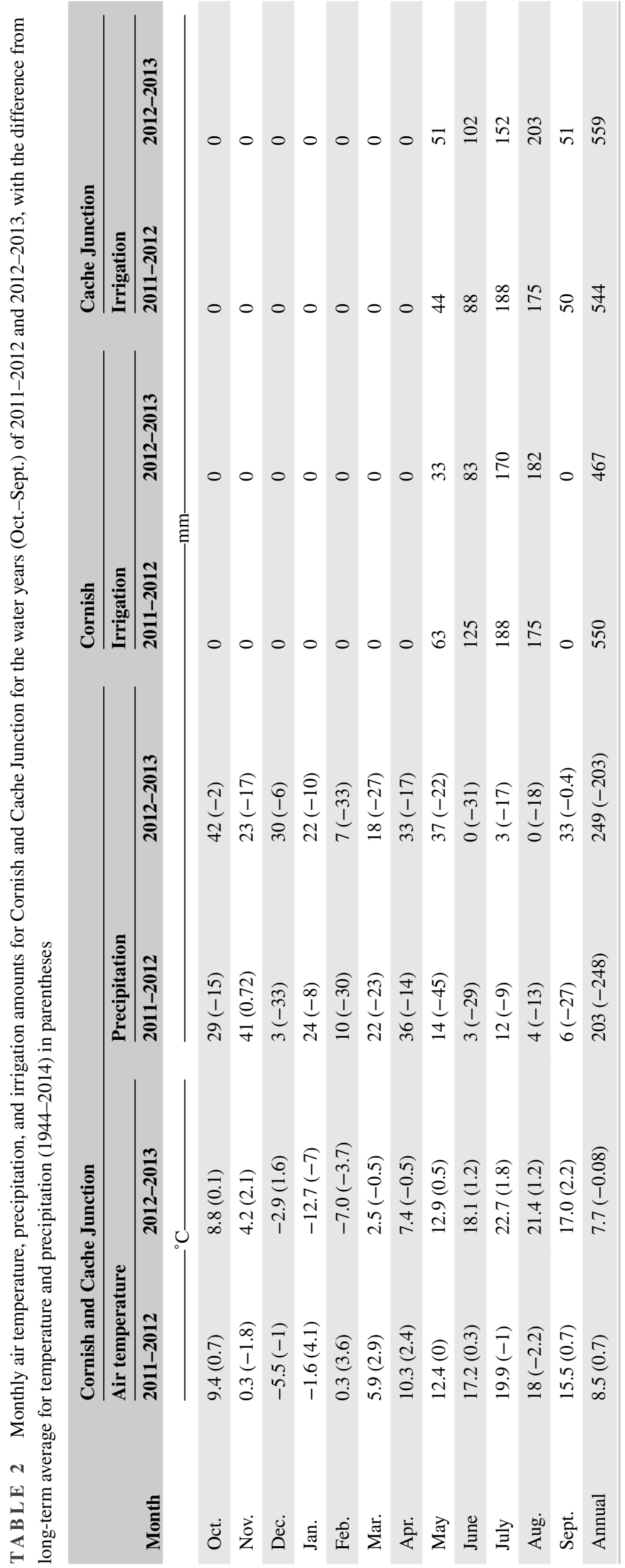


regrowth height was determined by measuring alfalfa stem height within each subplot before each herbicide application timing (Table 3). Alfalfa regrowth biomass was determined by hand clipping plants at the soil surface in two $0.5-\mathrm{m}^{2}$ areas per replication in the nontreated control (no-till and no herbicide) before each herbicide application timing. Regrowth samples were weighed, dried in a forced-air oven at $60{ }^{\circ} \mathrm{C}$ until constant mass, and weighed again to determine dry matter yield. Final alfalfa plant population was determined at the same time as the fall herbicide application timing by digging up alfalfa plants inside two $0.5-\mathrm{m}^{2}$ quadrats per replication and counting the number of crowns.

The fall application timing occurred between 4 and 15 October of each year after at least $6 \mathrm{~cm}$ of alfalfa regrowth had occurred following the last alfalfa cutting. The spring herbicide application timing occurred 28 Apr. 2012 and 24 Apr. 2013 ( $2 \mathrm{wk}$ before the desired tilling date). The in-crop herbicide application timing occurred 3-4 wk after corn planting when the corn was approximately at the V2-V3 development stage (8 and 15 June 2012 in Cornish and Cache Junction, respectively, and 17 June 2013 for both sites). This practice simulated a farmer harvesting the spring cutting of alfalfa, planting corn immediately, and controlling the glyphosateresistant alfalfa 3-4 wk later at approximately the V2-V3 corn development stage. No herbicide was applied to the nontreated control.

Dekalb corn hybrid DKC 55-24 (Monsanto) was planted with a four-row no-till planter (Model NG Plus 4, Monosem Inc.) $5-\mathrm{cm}$ deep in $76-\mathrm{cm}$ rows at 93,860 seeds $\mathrm{ha}^{-1}$. Cornish was planted on 12 May 2012 and 24 May 2013. Cache Junction was planted on 21 May 2012 and 17 May 2013. Acetochlor (2-chloro-2'-methyl-6'-ethyl-Nethoxymethylacetanilide) at $1,789 \mathrm{~g}$ a.i. $\mathrm{ha}^{-1}$ plus paraquat ( $1,1^{\prime}$ dimethyl-4,4'-bipyridinium dichloride) at $841 \mathrm{~g}$ cation $\mathrm{ha}^{-1}$ and nonionic surfactant at $0.25 \% \mathrm{v} / \mathrm{v}$ were applied at a spray volume of $187 \mathrm{~L} \mathrm{ha}^{-1}$ on the planting date for weed control and to burndown the existing alfalfa so plots were void of green vegetation at the time of corn emergence, as would producers who recently harvested their alfalfa. A broadcast application of $224 \mathrm{~kg} \mathrm{~N} \mathrm{ha}^{-1}$ liquid $32 \%$ urea-ammonium nitrate solution was applied across all plots within $7 \mathrm{~d}$ after planting and immediately sprinkler irrigated with approximately $25 \mathrm{~mm}$ of water to incorporate the fertilizer.

\section{2 | Soil characteristics and plant measurements}

Penetration resistance was measured 6-7 wk after planting and $4 \mathrm{~d}$ after each site was evenly irrigated. The measurement was taken in each main plot within the spring herbicide treatment using a CP40II Cone Penetrometer (Rimik) with a cone size of $130 \mathrm{~mm}^{2}$. Three insertions were made and averaged

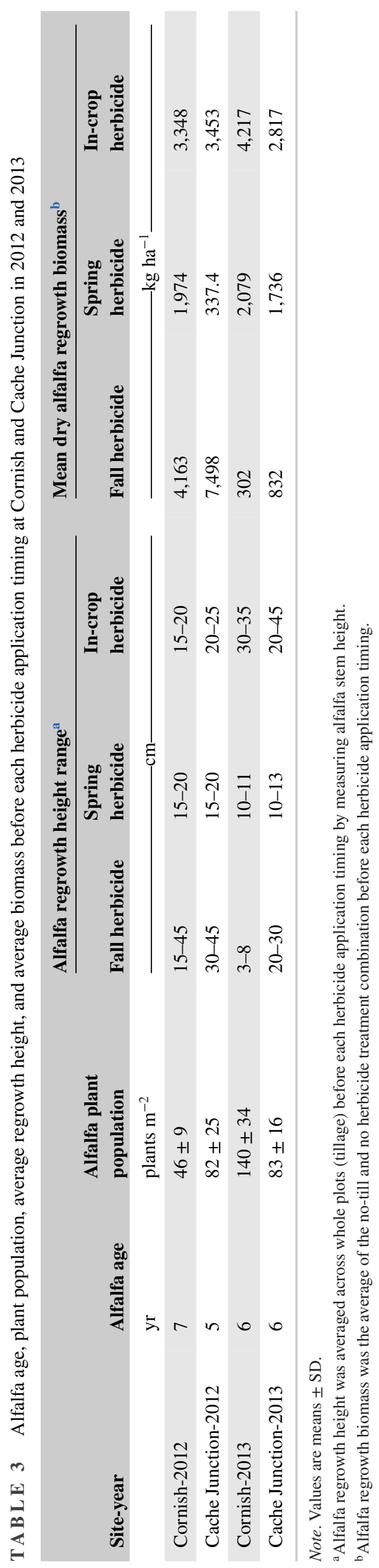


per main plot at a rate of 0.2 to $4 \mathrm{~m} \mathrm{~min}^{-1}$ with readings every $5 \mathrm{~cm}$ to a depth of $60 \mathrm{~cm}$. Due to equipment problems, only data from 2013 are presented in this paper.

Emergence rate was calculated by marking $5.3 \mathrm{~m}$ of two rows in each subplot before corn started emerging. Once corn began to emerge, the number of emerged corn plant was recorded each day until emergence was considered complete. The emergence rate index was then calculated following the method described in Erbach (1982). As the emergence rate index increases, the number of days from planting to full emergence decreases.

Alfalfa control was determined by measuring alfalfa density and biomass between the center two rows in each subplot 2 wk prior to corn harvest. Alfalfa stem counts were collected either by determining the number of stems in a $0.5-\mathrm{m}^{2}$ quadrat in two locations per subplot (nontreated controls in strip-till and no-till) or by counting the number of stems in the entire subplot (all other plots; $5.2 \mathrm{~m}^{2}$ in 2012 and $6.27 \mathrm{~m}^{2}$ in 2013). Similarly, biomass samples were obtained by hand clipping alfalfa at ground level in two $0.5-\mathrm{m}^{2}$ quadrats or the entire subplot. Samples were weighed, dried in a forced-air oven at $60{ }^{\circ} \mathrm{C}$, and weighed again to determine dry matter yield.

The center two rows of each subplot were harvested with a two-row pull behind corn silage chopper (Model 865, Gehl) between 25 Sept. and 9 Oct. 2012 and between 1 and 7 Oct. 2013. The chopped silage was blown into a weigh bin mounted on load cells that measured the weight for each plot, after which a 1-kg subsample was collected to determine moisture. Each sample was weighed, dried at $60^{\circ} \mathrm{C}$ in a forced air oven for $7 \mathrm{~d}$ until constant mass, and weighed again to determine dry matter yield.

\section{3 | Statistical analysis}

Penetration resistance, alfalfa biomass, alfalfa stem count, emergence rate index, and silage yield were evaluated using the MIXED procedure of SAS 9.4 (SAS Institute Inc.) at $\alpha=.05 . \log _{10}(\mathrm{x}+1)$ transformations were used for alfalfa biomass and average alfalfa stem count $\mathrm{m}^{-2}$ before analysis to meet normality and constant variance assumptions. Penetration resistance, emergence rate index, and silage yield met assumptions and were not transformed. Penetration resistance was evaluated at each site as a split-plot with four blocked replicates, tillage as the whole plot factor, and depth the subplot factor. Tillage and depth and their interactions were considered fixed effects, and blocks and its interactions were considered random effects. When fixed effects were significant a $P \leq .05$, least square means were calculated for tillage at each depth using the LSMeans statement and differences between them were determined using the simulate method to adjust for multiple comparisons. Alfalfa biomass, alfalfa stem count, emergence rate index, and silage yield were eval-
TA B L E 4 Degrees of freedom (df), F-value, and significance level for the effects of tillage, soil profile depth, and their interactions for penetration resistance at Cornish (coarse-textured soil) and Cache Junction (fine-textured soil) in only 2013

\begin{tabular}{llll} 
& & \multicolumn{2}{l}{$\begin{array}{l}F \text {-value and significance level of } \\
\text { fixed and random effects }\end{array}$} \\
\cline { 3 - 4 } $\begin{array}{l}\text { Source of } \\
\text { variation }\end{array}$ & df & Cornish & $\begin{array}{l}\text { Cache } \\
\text { Junction }\end{array}$ \\
\hline Tillage (T) & 4 & 5.01 & $8.60^{*}$ \\
\hline Depth (D) & 59 & $159.84^{*}$ & $52.00^{*}$ \\
\hline $\mathrm{T} \times \mathrm{D}$ & 236 & $1.53^{*}$ & $2.52^{*}$ \\
\hline
\end{tabular}

*Significant at the .05 probability level.

uated as a split-plot with four site-years, four blocked replicates, tillage as the whole plot factor, and herbicide as the subplot factor. Site-year, tillage, herbicide, and their interactions were considered fixed effects, and block and its interactions were considered random effects. When fixed effects were significant a $P \leq .05$, least square means were calculated for site-year, tillage, herbicide, and their interactions using the LSMeans statement, and the differences between them were determined using the simulate method to adjust for multiple comparisons.

\section{3 | RESULTS AND DISCUSSION}

\section{1 | Penetration resistance}

Soil texture and the tillage $\times$ depth interaction influenced the effect of tillage on penetration resistance (Table 4). On the coarse-textured soil, tillage operations only reduced penetration resistance compared with no-till to the depth of $25 \mathrm{~cm}$ for spring conventional tillage, $5 \mathrm{~cm}$ for fall conventional tillage, $10 \mathrm{~cm}$ for spring strip-till, and at no depth for fall strip-till (Figure 1), which was not to the full depth of conventional till $(45 \mathrm{~cm})$ or strip-till $(25 \mathrm{~cm})$. Conversely, on the fine-textured soil, tillage operations reduced penetration resistance compared with no-till to near the depth of conventional and strip-till. Differences in penetration resistance between conventional-till and strip-till were minimal in the coarse-textured soil, whereas in the fine-textured soil, fall and spring conventional-till $<$ fall and spring strip-till below the depth of strip-till $(25 \mathrm{~cm})$ to near the depth of conventionaltill $(45 \mathrm{~cm})$. Other studies on medium- to fine-textured soils also found that penetration resistance was greater in no-till than conventional and conservation tillage practices (strip-till, chisel plow, coulter) to near the depth of tillage (Janovicek, Deen, \& Vyn, 2006; Licht \& Al-Kaisi, 2005; Opoku, Vyn, \& Swanton, 1997; Vetsch \& Randall, 2002; Vetsch, Randall, \& Lamb, 2007; Vyn \& Raimbult, 1993). These results indicate that tillage operations compared with 


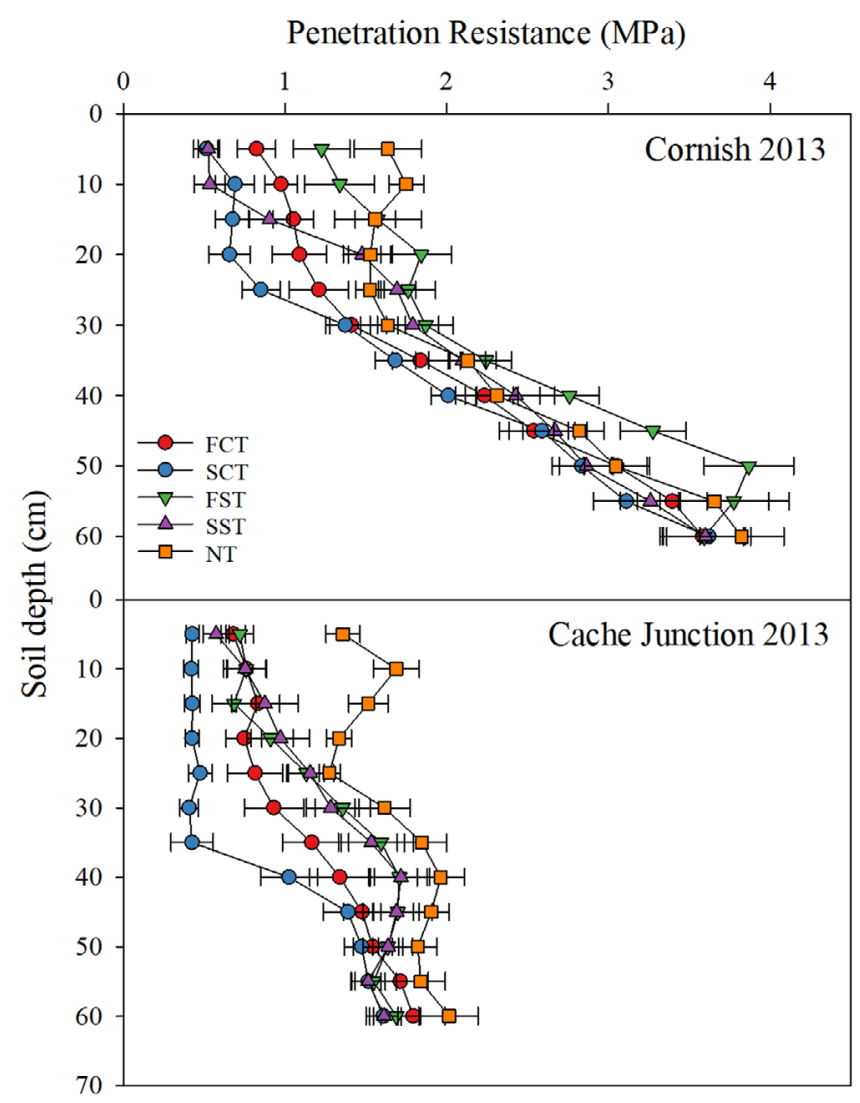

F I G U R E 1 Penetration resistance of the soil profile $(0-60 \mathrm{~cm})$ as affected by tillage type and timing at Cornish (coarse-textured soil) and Cache Junction (fine-textured soil), Utah in 2013. Error bars represent 1 SEM. FCT, fall conventional tillage; FST, fall strip-till; NT, no-till; SCT, spring conventional tillage; SST, spring strip-till

no-till better reduced penetration resistance to the depth of tillage in the fine-textured compared with the coarse-textured soil. More site-years comparing the effect of tillage on penetration resistance in coarse-textured and fine-textured soils are needed to compare the consistency of these findings.

\section{2 | Alfalfa stand termination}

Alfalfa control, measured by fall alfalfa stem counts and biomass, was influenced by the site $\times$ tillage $\times$ herbicide interaction (Table 5). Alfalfa stem counts and biomass ranged from 1 to 377 stems $\mathrm{m}^{-2}$ and from 1 to $4,214 \mathrm{~kg} \mathrm{ha}^{-1}$, respectively (Figures 2 and 3; Supplemental Tables S3 and S4). There were some statistically significant differences in the effect of the herbicide $\times$ tillage interaction on alfalfa control among site-years, but these differences were minimal, and each siteyear followed the same general trend. Generally, compared with no-till plus no herbicide (mean stems $\mathrm{m}^{-2}=263$, mean biomass $=3,474 \mathrm{~kg} \mathrm{ha}^{-1}[0 \%$ control]), all herbicide timing (fall, spring, and in-crop) and tillage type and timing combi-

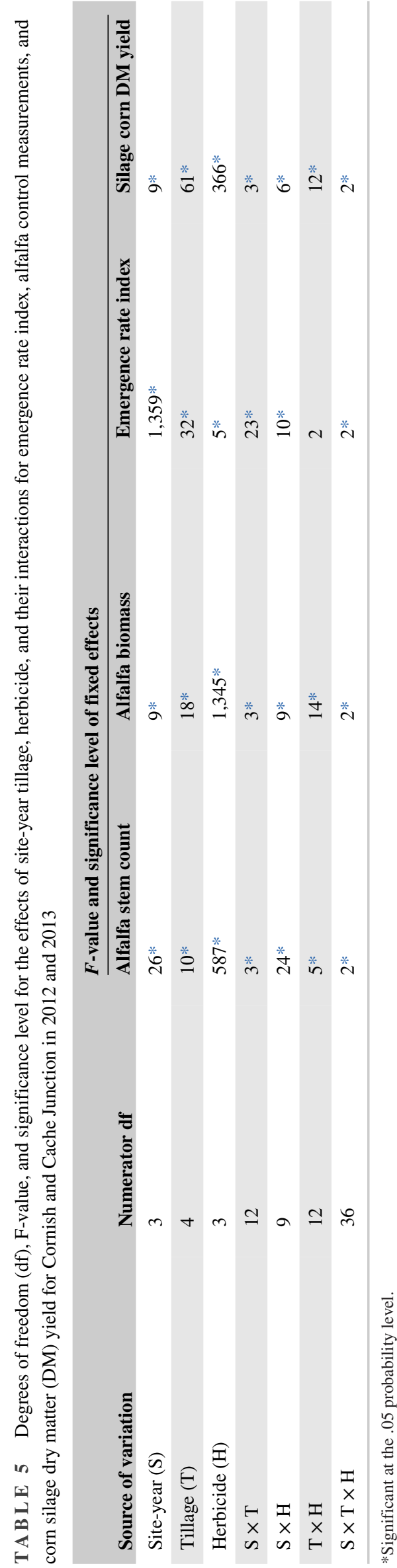




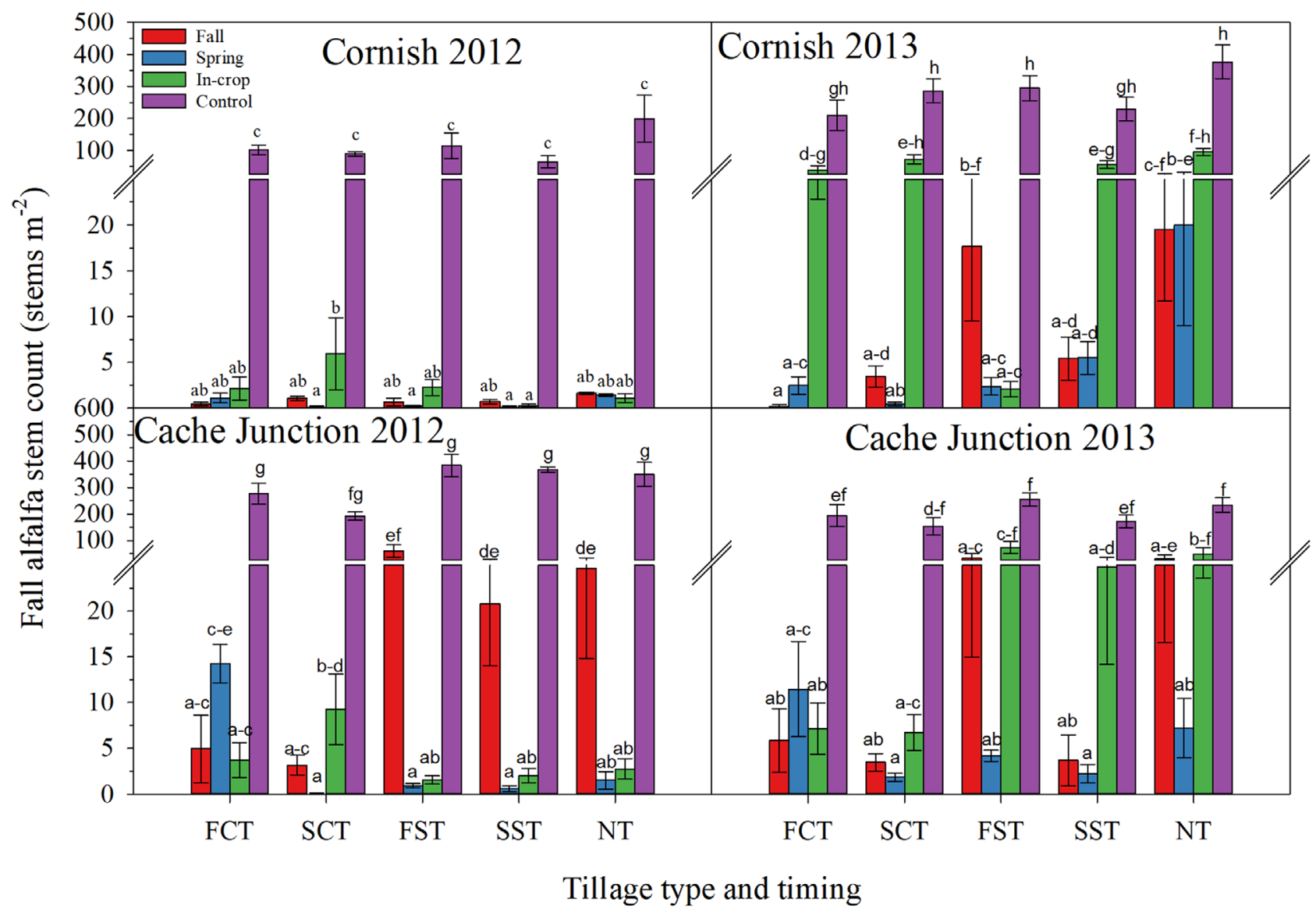

F I G U R E 2 Alfalfa stem count as a function of the interaction of tillage type and timing and herbicide application timing (fall, spring, in-crop, and a control with no herbicide application) at Cornish and Cache Junction, UT, in 2012 and 2013. Mean values with different letters within each site-year are statistically different $(P \leq .05)$. Error bars represent 1 SEM. FCT, fall conventional tillage; FST, fall strip-till; NT, no-till; SCT, spring conventional tillage; SST, spring strip-till

nations (fall conventional tillage, spring conventional tillage, fall strip-till, spring strip-till, and no-till) controlled an average of $97 \%$ of the alfalfa stands. These results indicate that herbicides alone in no-till situations or combined with striptill or conventional-till can effectively control glyphosateresistant alfalfa. Few other studies have evaluated termination strategies for glyphosate-resistant alfalfa. When terminating a non-glyphosate-resistant alfalfa in northeastern Nebraska, alfalfa was generally best controlled with herbicides in the spring opposed to the fall except where spring temperatures were $3.3{ }^{\circ} \mathrm{C}$ below normal from planting to corn emergence (Moomaw \& Martin, 1976). Their results also indicated that daytime temperatures below $15.6{ }^{\circ} \mathrm{C}$ reduced herbicide effect on alfalfa control. In our study, the similarity in fall vs. spring herbicide applications controlling alfalfa was likely due to our fall and spring temperatures being above $15.6{ }^{\circ} \mathrm{C}$ from planting to corn emergence.

Using tillage alone (fall conventional tillage, spring conventional tillage, fall strip-till, spring strip-till with no herbicide) reduced the percentage of alfalfa control to 29 vs. $97 \%$ where herbicides were included (Figures 2 and 3; Supplemen- tal Tables S3 and S4). Among the tillage-only treatments, fall alfalfa stem counts and biomass were best controlled using fall and spring conventional tillage (mean alfalfa stem count control $=34 \%$; mean alfalfa biomass control $=42 \%$ ) followed by fall and spring strip-till (mean alfalfa stem count control $=21 \%$; mean alfalfa biomass control $=20 \%$ ), with the spring tillage timings better controlling alfalfa in three of four site-years by an average of $16 \%$. In other related studies with non-glyphosate-resistant alfalfa, more aggressive tillage practices (two passes with a disk or rototiller or a single pass with a moldboard plow) than our conventional tillage practice controlled alfalfa similar to only using herbicides (Bullied et al., 1999; Moomaw \& Martin, 1976; Moyer et al., 2003). These results suggest that more aggressive tillage may also reduce the need for herbicides to terminate glyphosateresistant alfalfa. Alfalfa control was numerically, but not statistically, better when herbicides were applied before and in the same season as when conventional tillage was completed (e.g., fall conventional tillage plus fall herbicide timing or spring conventional tillage plus spring herbicide timing) (Figures 2 and 3; Supplemental Tables S3 and S4). For 


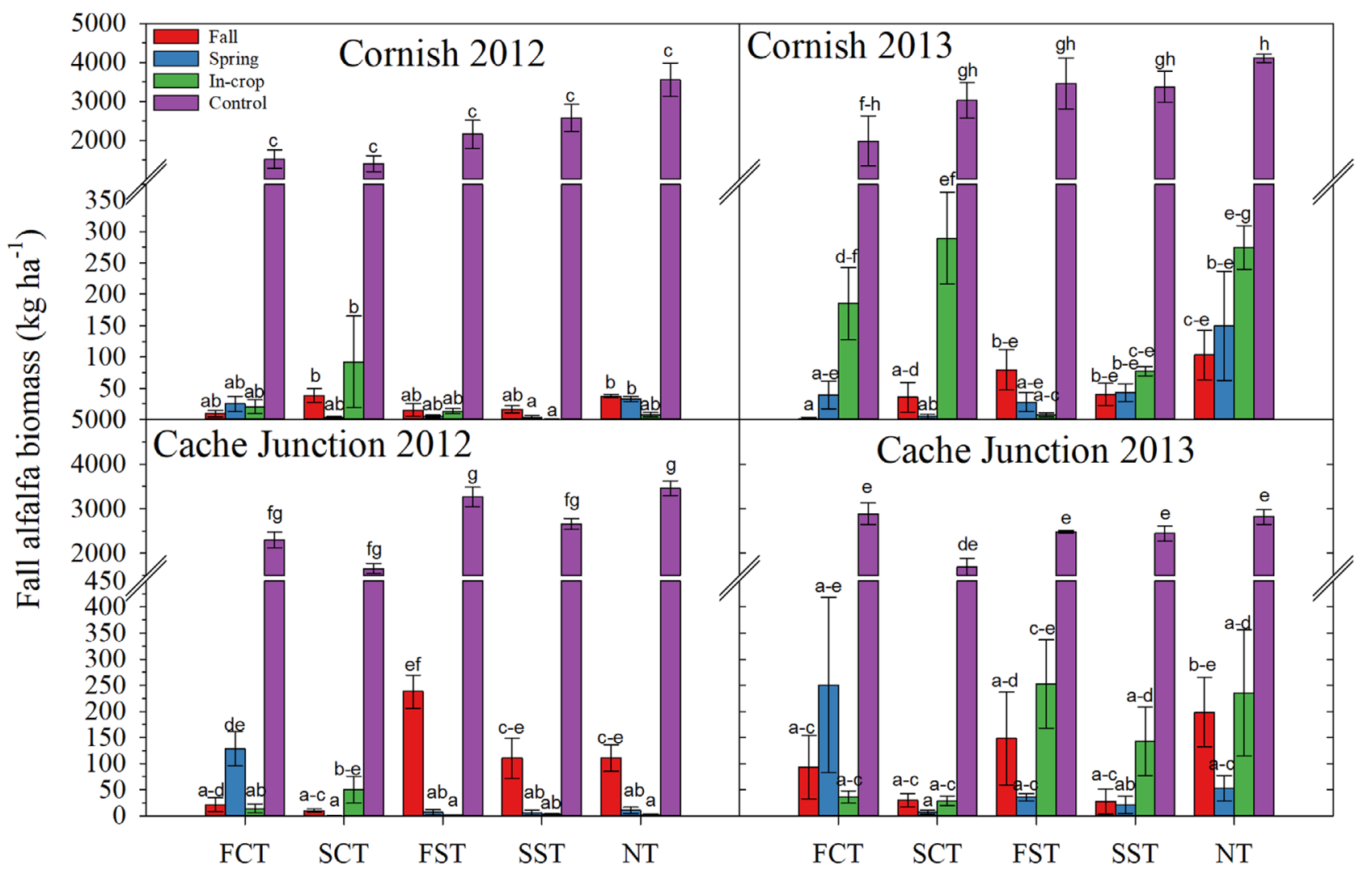

Tillage type and timing

F I G U R E 3 Alfalfa biomass as a function of the interaction of tillage type and timing and herbicide application timing (fall, spring, in-crop, and a control with no herbicide application) at Cornish and Cache Junction, UT, in 2012 and 2013. Mean values with different letters within each site-year are statistically different $(P \leq .05)$. Error bars represent 1 SEM. FCT, fall conventional tillage; FST, fall strip-till; NT, no-till; SCT, spring conventional tillage; SST, spring strip-till

example, in the fall conventional tillage treatment, the average alfalfa biomass for the fall herbicide timing was $8 \mathrm{~kg}$ $\mathrm{ha}^{-1}$ but increased to 71 and $48 \mathrm{~kg} \mathrm{ha}^{-1}$ in the spring and in-crop herbicide timings, respectively. Before tillage operations occur there are many alfalfa stems leading to a single large root, whereas after tillage that large root is broken up into many small roots that have fewer stems than the original root, increasing the difficulty in translocating sufficient herbicide to kill all the roots. In addition, the alfalfa that survived tillage operations may have still been buried or not yet recovered and actively growing again after the tillage operations before herbicides were applied. It may also be important to spray and till in the same season because the alfalfa plants that the herbicide treatment did not kill but only weakened were less likely to survive when tillage occurred before the plant could recover. The fall, spring, and in-crop herbicide timings when combined with fall or spring strip-till were similar in controlling the alfalfa stem count and biomass, indicating herbicide application timing did not make a difference in a strip-till system.

\section{3 | Corn emergence}

The emergence rate index used in this study is a measure of how quickly corn completed emergence once it began (i.e., larger numbers indicate faster germination). The emergence rate index was influenced by the site $\times$ tillage $\times$ herbicide interaction (Table 5). The emergence rate index ranged from a maximum of 9.2 in the spring conventional tillage plus fall herbicide timing to a minimum of 6.3 in the fall strip-till plus spring herbicide timing (Figure 4; Supplemental Table S5). There were some differences in the effect of the herbicide $x$ tillage interaction on emergence rate index among site-years, but these differences were minimal, and each site-year followed the same general trend. Generally, regardless of herbicide timing, the emergence rate index was greatest in fall and spring conventional tillage and spring strip-till (mean maximum emergence rate index $=8.8$ ) followed by fall strip-till and no-till (mean maximum emergence rate index $=8.2$ ). In two of the four site-years, fall strip-till and no-till combined with the spring herbicide timing had a similar emergence rate 


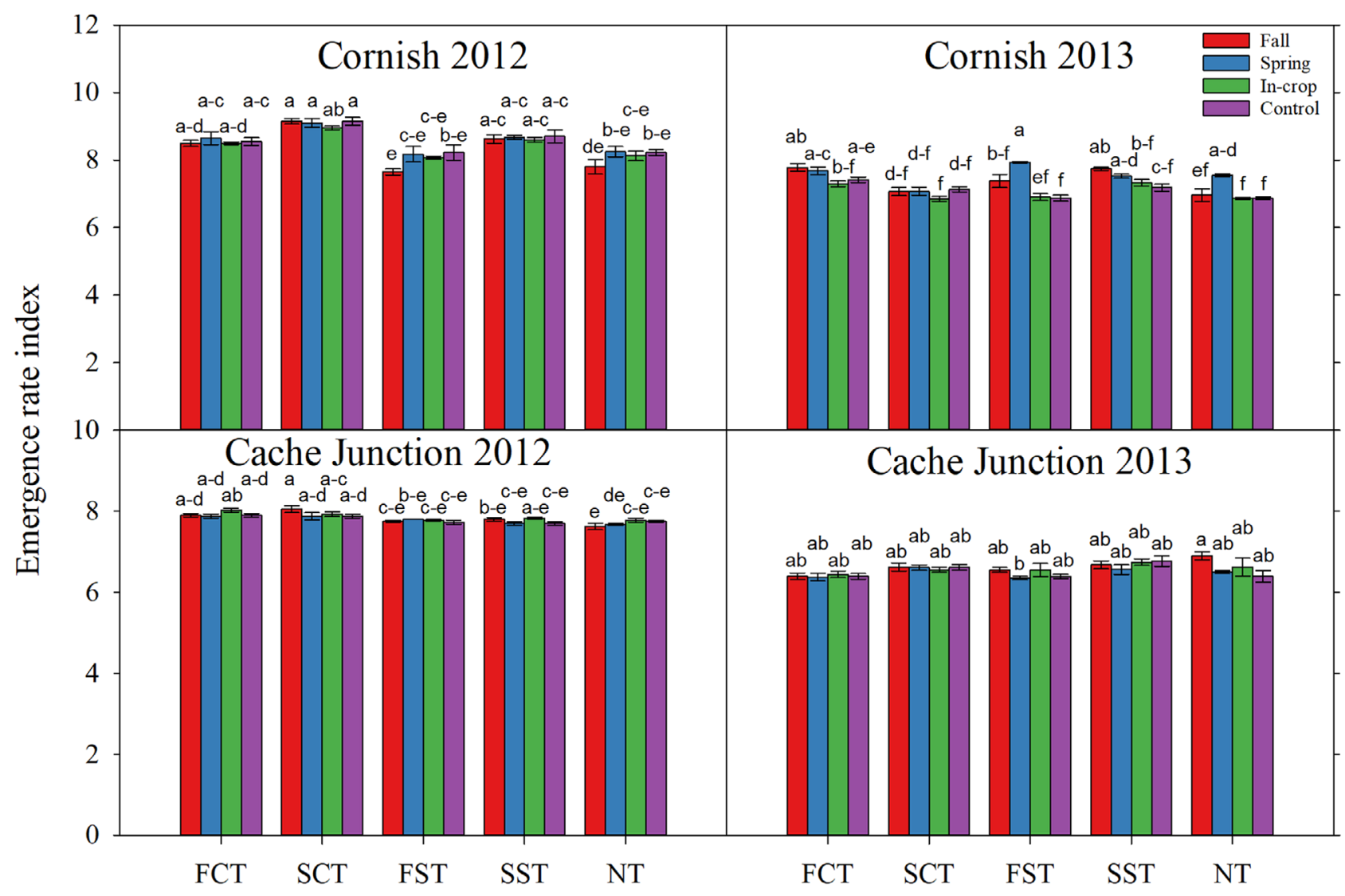

Tillage type and timing

F I G U R E 4 Emergence rate index (larger numbers indicate faster germination) as a function of the interaction of tillage type and timing and herbicide application timing (fall, spring, in-crop, and a control with no herbicide application) at Cornish and Cache Junction, UT, in 2012 and 2013. Mean values with different letters within each site-year are statistically different $(P \leq .05)$. Error bars represent 1 SEM. FCT, fall conventional tillage; FST, fall strip-till; NT, no-till; SCT, spring conventional tillage; SST, spring strip-till

index as fall and spring conventional tillage and spring striptill. These results indicate that conservation tillage practices including strip-till and no-till can have similar corn emergence rates as conventional tillage practices most consistently when strip-till is completed in the spring and herbicides were applied to no-till areas in the spring. Another study in southern Ontario on a loamy sand soil reported similar spring soil temperatures and corn emergence rates for conventional tillage and strip-till systems (Beyaert et al., 2002).

Alfalfa residue covering the soil surface can reflect solar radiation and slow the warming of the soil in the spring and is likely the reason the no-till treatments had a lower emergence rate index than fall and spring conventional tillage and spring strip-till treatments. Both timings of conventional tillage buried the majority of the plant residue, likely allowing the soil to absorb most of the available solar radiation to quickly warm the soil in the spring, resulting in conventional tillage systems generally having the highest emergence rate index. Because strip-till removes the residue in a 20 - to $30-\mathrm{cm}$ area, soil temperatures and crop emergence rates can be similar to that of conventional tillage (Shinners, Nelson, \& Wang, 1994). This finding supports our results because the emergence rate indices of spring strip-till treatments were similar to fall and spring conventional tillage treatments. However, the emergence rate indices of fall strip-till treatments were lower, potentially because fall strip-till may have had some spring weeds expand into the tilled area from the nontilled area in the early spring that reflected solar radiation and slowed the warming of the soil in the spring, reducing the emergence rate index. These differences in emergence rate index due to tillage type and timing and herbicide application timing were statistically different but small. This finding supports those of Licht and Al-Kaisi (2005), who reported that, in Iowa on loam and silty clay loam soils, the emergence rate index differences between tillage systems (no-till, striptill, and chisel plow) were larger when air temperatures were lower than normal compared with higher than normal (as our air temperatures were in all site-years; Table 2). 


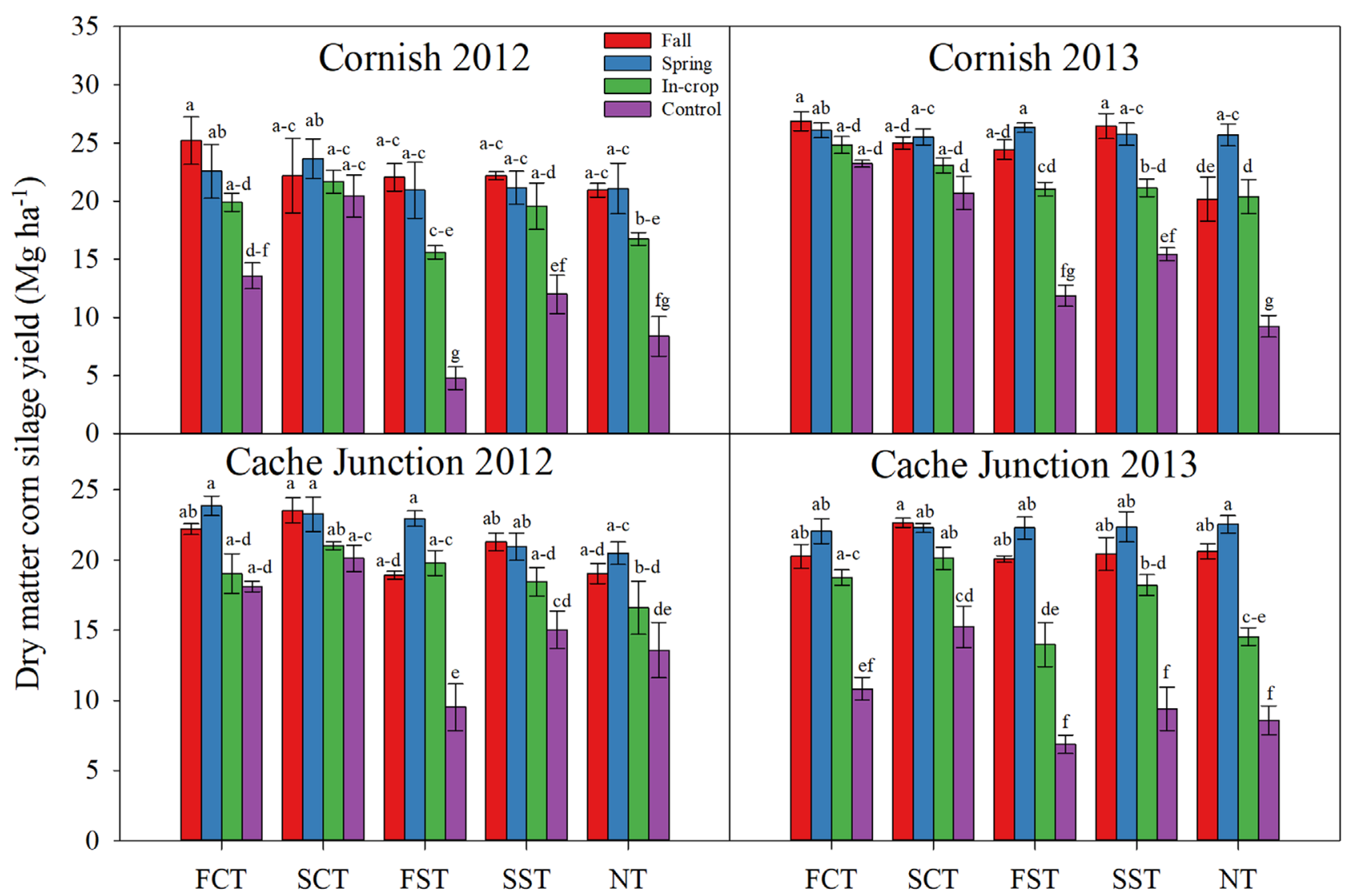

Tillage type and timing

F I G U R E 5 Corn silage dry matter yield as a function of the interaction of tillage type and timing and herbicide application timing (fall, spring, in-crop, and a control with no herbicide application) at Cornish and Cache Junction, UT in 2012 and 2013. Mean values with different letters within each site-year are statistically different $(P \leq .05)$. Error bars represent 1 SEM. FCT, fall conventional tillage; FST, fall strip-till; NT, no-till; SCT, spring conventional tillage; SST, spring strip-till

\section{4 | Silage corn yield}

Dry matter silage corn yield was influenced by the site $x$ tillage $\times$ herbicide interaction (Table 5). Silage yields ranged from 20 to $27 \mathrm{Mg} \mathrm{ha}^{-1}$ in the fall conventional tillage plus fall herbicide timing treatment to $5-12 \mathrm{Mg} \mathrm{ha}^{-1}$ in the fall strip-till plus control herbicide timing treatment (Figure 5; Supplemental Table S6). There were some differences in the effect of the herbicide $\times$ tillage interaction on silage yield among sites, but these differences were minimal, and each site-year followed the same general trend. Generally, silage corn yield decreased as tillage intensity decreased (moving from conventional-till to strip-till or no-till), and herbicide timing moved from fall or spring to an in-crop or no herbicide treatment.

The highest-yielding treatments were combinations of fall and spring conventional tillage with fall, spring, or in-crop herbicide applications and fall and spring strip-till and no-till with fall or spring herbicide applications (19-27 $\mathrm{Mg} \mathrm{ha}^{-1}$ )
(Figure 5; Supplemental Table S6). The next highest-yielding combinations were fall and spring conventional tillage without herbicide applications and fall and spring strip-till and notill with the in-crop herbicide application (14-20 $\mathrm{Mg} \mathrm{ha}^{-1}$ ). The lowest-yielding treatments were fall and spring strip-till and no-till without herbicide applications $\left(5-15 \mathrm{Mg} \mathrm{ha}^{-1}\right)$. Soil compaction is often a concern after alfalfa termination, and our results showed penetration resistance up to the depth of tillage was often greater in no-till compared with striptill and conventional-till (Figure 1); however, silage yield was similar regardless of tillage type and timing when alfalfa was properly controlled (Figure 5).

Other studies in the United States and Canada using conventional or conservation tillage practices resulted in similar corn yields (Aflakpui et al., 1994; Beyaert et al., 2002; Carter, Berg, \& Sanders, 1991; Omololu, Sultana, Darapuneni, Beck, \& Steiner, 2019; Smith, Carter, \& Imholte, 1992), as was true in our study when herbicides were applied in the fall or spring to terminate the glyphosate-resistant alfalfa. However, there 
are studies in which yields differ based on tillage. For example, in Ontario on a loam soil, corn yield using no-till was less than conventional tillage in one of two years (Aflakpui et al., 1993), and in Minnesota on a clay loam soil conventional tillage corn yield was similar to that of strip-till and greater than no-till (Randall et al., 2001; Vetsch \& Randall, 2004). In the locations and years where no-till reduced corn yield compared with conventional tillage, it was likely caused by inadequate soil moisture and low early-season air temperatures, reducing corn emergence and early-season growth in no-till areas (Aflakpui et al., 1993, 1994). The no-till and conventionally tilled areas in our coarse- and fine-textured soils likely yielded similarly because soil moisture at time of planting was optimized with irrigation when needed and because early-season air temperatures were adequate to result in soil temperatures that would not significantly reduce crop growth.

Using conventional or strip tillage in the fall or spring, regardless of herbicide application timing (fall, spring, or incrop), resulted in similar silage corn yields (Figure 5; Supplemental Table S6). Specifically, across herbicide application timings, silage corn yields for fall vs. spring tillage timings were on average within $1.5 \mathrm{Mg} \mathrm{ha}^{-1}$ using conventional tillage and $1.3 \mathrm{Mg} \mathrm{ha}^{-1}$ using strip-till. In other studies in Minnesota and Wisconsin on medium- and fine-textured soils, corn yields after fall or spring tillage operations were similar using disk-chisel tillage and moldboard plow plus two diskings (Smith et al., 1992; Yost, Coulter, Russelle, Sheaffer, \& Kaiser, 2012). These results indicate that growers can complete conventional-till or strip-till operations in the fall or wait until spring without affecting corn yield. Being able to wait until spring to complete tillage operations is beneficial because it allows growers to wait until after they can assess alfalfa stands for winterkill before making the decision to rotate to corn.

Due to the potential of shading and competition for water and nutrients between the alfalfa and corn, it is critical that $>90 \%$ of the alfalfa be controlled during the first $3 \mathrm{wk}$ after the corn is planted so its emergence, development, and yield are not reduced (Mercurio \& Buhler, 1985; Moomaw \& Martin, 1976). The fall and spring herbicide applications were likely able to sufficiently control the alfalfa during this critical time, resulting in all the tillage treatments when combined with the fall or spring herbicide timing to yield similarly. The in-crop timings within fall and spring strip-till and notill likely allowed the alfalfa to compete with the corn during the critical weed-free time, reducing silage corn yield. The incrop application of 2,4-D plus dicamba may have also injured the corn to the point it was not able to recover enough to yield similarly as the fall and spring herbicide application timings. The fact that the in-crop herbicide timing of fall and spring conventional tillage did yield similarly to the fall and spring herbicide timings may have been because of their ability to control enough of the alfalfa with tillage operations through the critical period until herbicides were applied to fully terminate the alfalfa.

Using tillage systems alone to terminate glyphosateresistant alfalfa compared with using tillage plus herbicides or herbicides alone reduced corn silage yield an average of $8 \mathrm{Mg} \mathrm{ha}^{-1}$ (Figure 4; Supplemental Table S6). Silage corn yield was greatest to least without herbicide application, with fall and spring conventional tillage yielding between 11 and $23 \mathrm{Mg} \mathrm{ha}^{-1}$, spring strip-till yielding 9-15 $\mathrm{Mg} \mathrm{ha}^{-1}$, and fall strip-till and no-till yielding 5-14 $\mathrm{Mg} \mathrm{ha}^{-1}$. In northeastern Saskatchewan, Malhi et al. (2007) also determined that one or two tandem disk passes alone yielded less than when tillage plus herbicides were used to terminate the alfalfa stand. However, in the U.S. Midwest and Canada on mediumto fine-textured soils, more intensive tillage practices than ours including moldboard plowing, rototilling, and double disking alone compared with tillage with glyphosate or other herbicides controlled non-glyphosate-resistant alfalfa sufficiently as to not affect corn yield (Bullied et al., 1999; Moomaw \& Martin, 1976; Moyer et al., 2003; Smith et al., 1992). These results indicate that the reliance on herbicides to sufficiently control alfalfa and other weeds and optimize corn yield increases as tillage practices decrease in intensity.

\section{4 | CONCLUSIONS}

Non-glyphosate herbicides should be applied to terminate glyphosate-resistant alfalfa before corn planting to optimize corn emergence rates and corn silage yield for both conservation and conventional tillage systems. The fact that both fall and spring herbicide application timings sufficiently controlled glyphosate-resistant alfalfa and optimized corn silage yield indicates that growers could wait until spring to assess alfalfa stands for winterkill before deciding to terminate alfalfa. In cases where the first cutting of glyphosate-resistant alfalfa is harvested in the spring before corn planting and alfalfa is controlled during the corn growing season with nonglyphosate herbicides, growers should expect mean silage corn yield reductions of $1-4 \mathrm{Mg} \mathrm{ha}^{-1}$ using conventional tillage, $1-7 \mathrm{Mg} \mathrm{ha}^{-1}$ using strip-till, and $2.5-7 \mathrm{Mg} \mathrm{ha}^{-1}$ using no-till. However, this reduction in silage corn yield is offset some by the $2.8-4.2 \mathrm{Mg} \mathrm{ha}^{-1}$ alfalfa dry matter yield obtained from harvesting the first cutting of alfalfa before planting corn, making the use of an in-crop herbicide application to control glyphosate-resistant alfalfa after corn is planted a good option, especially in conventional-till or strip-till systems. Further, our results indicated that conventional-till and strip-till were able to reduce compaction compared with notill to near the depth of tillage, especially in fine-textured soils. However, the reduced compaction after conventionaltill or strip-till operations compared with no-till did not result in greater corn yield when herbicides were applied at 
the right timing (fall or spring) to minimize alfalfa to corn competition.

\section{AC KNOWLEDG MENTS}

This research was supported by the Utah Agricultural Experiment Station, Utah State University, and approved as journal paper number 9336. We thank the USDA-NRCS Conservation Innovation Grant program for financial support.

\section{CONFLICT OF INTEREST}

The authors declare no conflict of interest.

\section{O R C I D}

Jason D. Clark (10 https://orcid.org/0000-0001-7793-6411

Matt A. Yost (1) https://orcid.org/0000-0001-5012-8481

J. Earl Creech (1) https://orcid.org/0000-0002-4393-6816

\section{RE F E R E N C E S}

Aflakpui, G. K. S., Vyn, T. J., Anderson, G. W., Clements, D. R., Hall, M. R., \& Swanton, C. J. (1994). Crop management systems for corn (Zea mays L.) following established alfalfa (Medicago sativa L.). Canadian Journal of Plant Science, 74, 255-259. https://doi.org/10.4141/ cjps94-051

Aflakpui, G. K. S., Vyn, T. J., Hall, M. R., Anderson, G. W., \& Swanton, C. J. (1993). Effect of tillage on nitrogen response in corn (Zea mays L.) after established alfalfa (Medicago sativa L.). Canadian Journal of Plant Science, 73, 73-81. https://doi.org/10.4141/cjps93-010

Al-Darby, A. M., \& Lowery, B. (1987). Seed zone soil temperature and early corn growth with three conservation tillage systems. Soil Science Society of America Journal, 51, 68-773. https://doi.org/10.2136/ sssaj1987.03615995005100030035x

BASF. (2010). Clarity herbicide label. Retrieved from http://www.cdms. net/ldat/ld797012.pdf

Beyaert, R. P., Schott, J. W., \& White, P. H. (2002). Tillage effects on corn production in a coarse-textured soil in southern Ontario. Agronomy Journal, 94, 767-774. https://doi.org/10.2134/agronj2002.7670

Buhler, D. D., \& Mercurio, J. C. (1988). Vegetation management and corn growth and yield in untilled mixed-species perennial sod. Agronomy Journal, 80, 454-462. https://doi.org/10.2134/agronj1988. $00021962008000030013 x$

Bullied, W. J., Entz, M. H., \& Smith , S. R. Jr (1999). No-till alfalfa stand termination strategies: Alfalfa control and wheat and barley production. Canadian Journal of Plant Science, 79, 71-83. https: //doi.org/10.4141/P98-008

Carter, D. L., Berg, R. D., \& Sanders, B. J. (1991). Producing no-till cereal or corn following alfalfa on furrow-irrigated land. Journal of Production Agriculture, 4, 174-179. https://doi.org/10.2134/jpa1991. 0174

Darby, H. M., \& Lauer, J. G. (2002). Planting date and hybrid influence on corn forage yield and quality. Agronomy Journal, 94, 281-289. https://doi.org/10.2134/agronj2002.0281

Entz, M. H., Bullied, W. J., \& Katepa-Mupondwa, F. (1995). Rotational benefits of forage crops in Canadian prairie cropping systems. Journal of Production Agriculture, 8, 521-529. https://doi.org/10.2134/ jpa1995.0521

Erbach, D. (1982). Tillage for continuous corn and corn-soybean rotation. Transactions of the ASAE, 25, 906-911, 918.
Janovicek, K., Deen, W., \& Vyn, T. J. (2006). Soybean response to zone tillage, twin-row planting, and row spacing. Agronomy Journal, 98, 800-807. https://doi.org/10.2134/agronj2005.0231

Licht, M. A., \& Al-Kaisi, M. (2005). Strip-tillage effect on seedbed soil temperature and other soil physical properties. Soil \& Tillage Research, 80, 233-249. https://doi.org/10.1016/j.still.2004.03.017

Malhi, S. S., Johnston, A. M., Loeppky, H., Vera, C. L., Beckie, H. J., \& Bandara, P. M. S. (2007). Immediate effects of time and method of alfalfa termination of soil mineral nitrogen, moisture, weed control, and seed yield, quality, and nitrogen uptake. Journal of Plant Nutrition, 30, 1059-1081. https://doi.org/10.1080/01904160701394501

Malhi, S. S., Lemke, R., \& Schoenau, J. J. (2009). Influence of time and method of alfalfa stand termination on yield, seed quality, $\mathrm{N}$ uptake, soil properties and greenhouse gas emissions under different $\mathrm{N}$ fertility regimes. Nutrient Cycling in Agroecosystems, 86, 17-38. https://doi.org/10.1007/s10705-009-9271-x

Mercurio, J. C., \& Buhler, D. D. (1985). Control of alfalfa-perennial grass sod for no-till corn production. Proceedings North Central Weed Control Conference, 40, 47.

Mohr, R. M., Entz, M. H., Janzen, H. H., \& Bullied, W. J. (1999). Plant-available nitrogen supply as affected by method and timing of alfalfa termination. Agronomy Journal, 91, 622-630. https://doi.org/ 10.2134/agronj1999.914622x

Monsanto. (2019). Roundup PowerMAX herbicide label. Retrieved from http://www.cdms.net/ldat/ld8CC001.pdf

Moomaw, R. S., \& Martin, A. R. (1976). Herbicides for no-tillage corn in alfalfa sod. Weed Science, 24, 449-453.

Moyer, J. R., Clapperton, M. J., \& Boswall, A. L. (2003). Method and time of alfalfa termination affects cereal growth and weed populations. Canadian Journal of Plant Science, 83, 969-976. https://doi. org/10.4141/P02-186

Omololu, J. I., Sultana, S., Darapuneni, M., Beck, L., \& Steiner, R. (2019). Short-term conservation tillage effects on corn silage yield and soil quality in an irrigated, arid agroecosystem. Agronomy, 9, 455. https://doi.org/10.3390/agronomy9080455

Opoku, G., Vyn, T. J., \& Swanton, C. J. (1997). Modified no-till systems for corn following wheat on clay soils. Agronomy Journal, 89, 549-556. https://doi.org/10.2134/agronj1997.000219620089000 40003x

Randall, G. W., Vetsch, J. A., \& Murrell, T. S. (2001). Corn response to phosphorus placement under various tillage practices. Better Crops, $85,12-15$.

Rogan, G., \& Fitzpatrick, S. (2004). Petition for determination of nonregulated status: Roundup ready ${ }^{\circledR}$ alfalfa (Medicago sativa L.) events J101 and J163. Retrieved from www.aphis.usda.gov/brs/aphisdocs/ 04_11001p.pdf

Shinners, K. J., Nelson, W. S., \& Wang, R. (1994). Effects of residuefree width on soil temperature and water content. Transactions of the ASAE, 3, 39-49.

Smith, M. A., Carter, P. R., \& Imholte, A. A. (1992). Conventional vs. no-till corn following alfalfa/grass: Timing of vegetation kill. Agronomy Journal, 84, 780-786. https://doi.org/10.2134/agronj1992. $00021962008400050004 x$

Soil Survey Staff. (2014a). Official soil series descriptions. USDANRCS. Retrieved from http://www.nrcs.usda.gov/wps/portal/nrcs/ detailfull/soils/home/?cid=nrcs142p2_053587

Soil Survey Staff. (2014b). Web soil survey: Soil data mart. USDANRCS. Retrieved from https://websoilsurvey.sc.egov.usda.gov/App/ HomePage.htm 
Steckel, L. E., Hayes, R. M., Montgomery, R. F., \& Mueller, T. C. (2007). Evaluating glyphosate treatments on roundup ready alfalfa for crop injury and feed quality. Forage and Grazinglands, 5(1). https://doi. org/10.1094/FG-2007-0201-01-RS

Van Deynze, A., Putnam, D. H., Orloff, S., Lanini, T., Canevari, M., Vargas, R., ... Teuber, L. (2004). Roundup ready alfalfa: An emerging technology. Davis, CA: University of California Division of Agriculture and Natural Resources.

Van Roekel, R. J., \& Coulter, J. A. (2011). Agronomic responses of corn to planting date and plant density. Agronomy Journal, 103, 14141422. https://doi.org/10.2134/agronj2011.0071

Vetsch, J. A., \& Randall, G. W. (2002). Corn production as affected by tillage system and starter fertilizer. Agronomy Journal, 94, 532-540. https://doi.org/10.2134/agronj2002.5320

Vetsch, J. A., \& Randall, G. W. (2004). Corn production as affected by nitrogen application timing and tillage. Agronomy Journal, 96, 502509. https://doi.org/10.2134/agronj2004.5020

Vetsch, J. A., Randall, G. W., \& Lamb, J. A. (2007). Corn and soybean production as affected by tillage systems. Agronomy Journal, 99, 952959. https://doi.org/10.2134/agronj2006.0149

Vyn, T. J., \& Raimbult, B. A. (1993). Long-term effect of five tillage systems on corn response and soil structure. Agronomy Journal, 85, 1074-1079. https://doi.org/10.2134/agronj1993. $00021962008500050022 x$
Winfield. (2020). 2,4-D LV6 herbicide label. Winfield Solutions, LLC. Retrieved from http://www.cdms.net/ldat/ld971000.pdf

Yost, M. A., Coulter, J. A., Russelle, M. P., Sheaffer, C. C., \& Kaiser, D. E. (2012). Alfalfa nitrogen credit to first-year corn: Potassium, regrowth, and tillage timing effects. Agronomy Journal, 104, 953962. https://doi.org/10.2134/agronj2011.0384

\section{S UPPORTING INFORMATION}

Additional supporting information may be found online in the Supporting Information section at the end of the article.

How to cite this article: Clark JD, Yost MA, Cardon GE, Ransom CV, Creech JE. Tillage method and glyphosate-resistant alfalfa termination timing affect soil properties and subsequent corn yield. Agronomy Journal. 2021;113:321-334. https://doi.org/10.1002/agj2.20478 